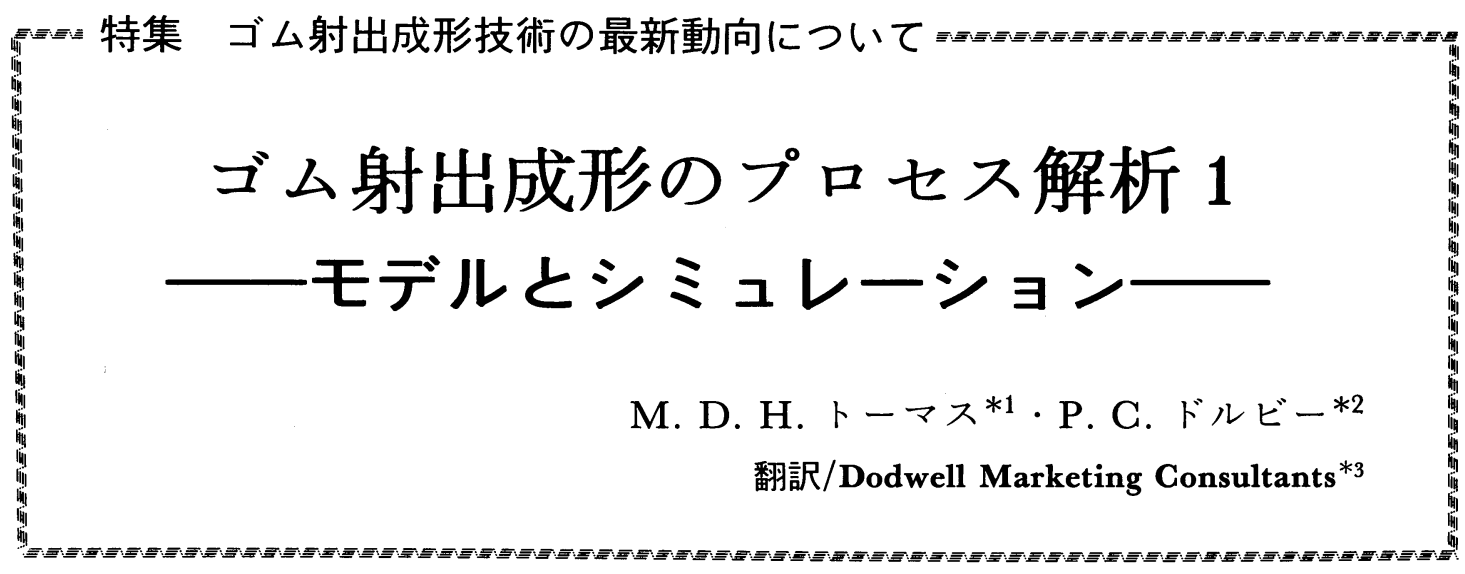

1. は じめに

射出成形加工は資本集約的工業である．使用さ れる機器は，高価であるため非稼働時間を最小に しなければならない，金型設計は伝統的に試行錯 誤を繰り返し，金型製造業者により大変な時間が 費やされている. 熱可塑性樹脂加工はコンピュー ターを使用して, 射出成形の流動と冷却をシミュ レーションするといら最新の技術を使っている.

しかし，ゴムの成形シミュレーション用のソフ トゥェアはほとんどない，市場規模に加え，熱可 塑性樹脂のシミュレーションが注目される理由が ある. 熱可塑性樹脂の特性記述は, 比較的理解し やすく大きな問題はない，その決定方法は多年に わたり開発されている。しかし，ゴムは加熱する ことにより加硫するので, 理論モデルと材料の特 性化の手法を使い解析されなければならない。

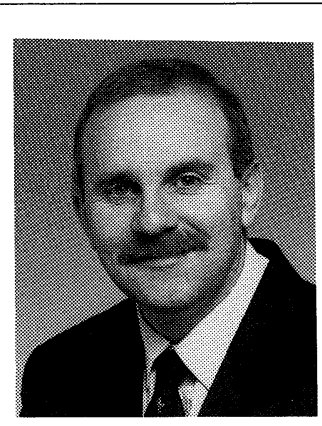

*1 ラプラ・テクノロジー社 (英国). 機械工学士. University College, Carditt $に$ て学位を取得. 後に, 流体 力学の学位も取得. Royal Ordanceにて設計技師とし て勤務を経て，ラプラ・テ クノロジー入社後, レオロ ジー，熱硬化性物質の流動 性, 繊維マット及び圧縮成 形の流動性のシミュレーシ ョンモデル開発に従事. 近年は本稿で述べた分野の研 究及びポリマー材料の射出成形のシミュレーションの 研究開発にたずさわっている. 英国栜許技師．機械技 術士学会会員.
本資料は，流動と加硫フェーズの理論的モデリ ングを材料行動モデリングとともに簡潔に説明す るものである. 例題は実例に即したものである.

\section{2. 数学的モデル}

\section{1 数学的モデル}

金型内でのゴムの流れは過渡的であり, 非ニュ 一トン系, 非等温で, かつ粘性を持つ流動であ る.したがって, 数学的モデルは, 質量, エネル ギーと運動量の各方程式から得られた連立方程式 でなければならない，方程式は, 粘性の温度依存 性により増える。

一般化されたヘレーショウ近似1 3)を使用して 金型内でのゴムの流れをシミュレーションするこ とができる，その近似条件は：

（i）流れはストークス流で，慣性項は無視できる

(ii) 断面は薄く, 厚さ方向の流れはないものとす

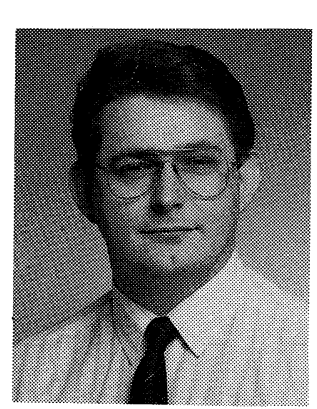

*2 ラプラ・テクノロジー社 (英国)。ソフトウェア技 師. ポリマーの射出成形, 圧縮成形及び押し出し成形 における有限要素モデルに 注力したポリマー業界用ソ フトウェア(外販用)の開発 に従事している. 


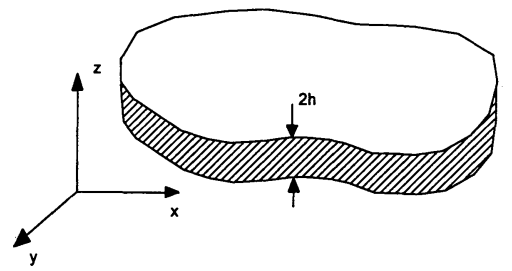

図 1

\section{る}

(iii) 熱移動は，流れ方向の熱の移流と厚さ方向の 熱伝導である

(iv) 材料は非圧縮性とする

数学的モデルの追加近似条件として，

（v）流れは，通常の粘性流と仮定し，壁面での滑 りはないものとする

(vi) 金型は，無限の熱の供給および吸収源と仮定 する (金型温度一定)

直交座標系，X，Yにおいてわずか $\mathrm{Z}$ だけ離れ ている平行な二つの面を考えると, 質量保存式は 以下のように記述される：

$$
\frac{\partial}{\partial x}\left(h \bar{u}_{x}\right)+\frac{\partial}{\partial y}\left(h \bar{u}_{y}\right)=0
$$

ここで, $\bar{u}_{x}$ と $\bar{u}_{y}$ は, ある地点 $(x, y)$ に拉ける $x$ 方 向, $y$ 方向の平均速度とし, $2 \mathrm{~h}$ は間隔である.

運動量の式は，以下のように導くことができる：

$$
\begin{aligned}
& \eta \frac{\partial u_{x}}{\partial z}=z \frac{\partial P}{\partial x} \\
& \eta \frac{\partial u_{y}}{\partial z}=z \frac{\partial P}{\partial y}
\end{aligned}
$$

$\eta$ は粘度， $P$ は圧力である.

中央と壁面の間で方程式(2)を積分し，下式の境界 条件を考慮することにより：

$$
\begin{aligned}
& u_{x}(z)=u_{y}(z)=0 \quad z=h \text { (壁面) } \\
& \frac{\partial u_{x}}{\partial z}=\frac{\partial u_{y}}{\partial z}=0 \quad z=0 \text { (中心線) }
\end{aligned}
$$

以下の一組の方程式が得られる：

$$
\begin{aligned}
& u_{x}(z)=-\frac{\partial P}{\partial x} \int_{z}^{h} \frac{z}{\eta} \cdot d z \\
& u_{y}(z)=-\frac{\partial P}{\partial y} \int_{z}^{h} \frac{z}{\eta} \cdot d z
\end{aligned}
$$

これを(1)に代入すると：

$$
\frac{\partial}{\partial x}\left(s \frac{\partial P}{\partial x}\right)+\frac{\partial}{\partial y}\left(s \frac{\partial P}{\partial y}\right)=0
$$

(5)式は，材料の流入口での圧力又は体積流量の いずれかの境界条件に対して解くことができる. メルトフロントでは圧力はゼロと仮定する.

摩擦せん断発熱モデルを追加すると, 薄板の内 部の熱の移動は軸方向の対流と厚さ方向の伝導に 主に支配される.

$$
\begin{aligned}
& \rho c_{p}\left(\frac{\partial \theta}{\partial t}+u_{x} \frac{\partial \theta}{\partial x}+u_{y} \frac{\partial \theta}{\partial y}\right) \\
&=K\left(\frac{\partial^{2} \theta}{\partial z^{2}}\right)+\eta\left(\left(\frac{\partial u_{x}}{\partial z}\right)^{2}+\left(\frac{\partial u_{y}}{\partial z}\right)^{2}\right)
\end{aligned}
$$

$p$ は密度, $c_{p}$ は比熱, $\theta$ は温度, $K$ は熱伝導率で ある。

上記の方程式で, 圧力場は 2 次元で解かれ，温度 場は 3 次元で解かれる(式(6)に式(4)を代入)。この 問題は有限要素一有限差分法を組み合わせて解か れ, 各点での厚さ方向での温度分布が求まる.

制御容積有限要素法 ${ }^{4}$ は, 圧力場に対してはラ プラス方程式5をを解くために用いられ，温度場に 対しては差分法5)が用いられる。 世ん断速度，世 ん断応力, 速度, 加硫のそれぞれの 3 次元分布が 計算される。

このタイプの流れは高ペクレ数であるために， エネルギー方程式では，アップウインドアルゴリ ズムを使用する.

フローフロントは, 要素に充てんされた割合で 進んでいく3,6 7). 流れが停止したとき, 方程式 (6)は以下のようになる.

$$
\frac{1}{\alpha} \frac{\partial \theta}{\partial t}=\frac{\partial^{2} \theta}{\partial z^{2}}
$$

ここで $\alpha$ は材料の熱拡散率である. $\left(\alpha=\frac{K}{p c p}\right)$ この式は，1次元の非定常熱伝導を示しており, 方程式(6)と同様な方法で解くことができる.

\section{2 材料の記述}

2.2 .1 粘 性 粘度は, せん断速度と温 度の 2 次関数としてモデル化される：

$$
\begin{aligned}
\ln \left(\eta_{a}\right)= & A_{00}+A_{01} X+A_{10} Y \\
& +A_{11} X Y+A_{02} X^{2}+A_{20} Y^{2} \\
& A_{00}, A_{01}, \ldots, A_{22} \text { 一定 } \\
& X=\ln (\dot{\gamma}) \\
& Y=\theta \\
& \eta_{\alpha} \text { 見かけの粘度 } \\
& \dot{\gamma}_{\alpha} \text { 見かけのせん断速度 }
\end{aligned}
$$

この関数は, 長さの異なる二つのキャピラリを使 って補正されたキャピラリ粘度計のデータから導 
かれる（データは，入口と出口効果が考慮され ている)

2.2.2 加 硫 加硫度は, モンサントキ ュアーレオメーターで測定した. 加硫の解析には ハンズとホースホールにより開発された方法9)を 用いた：

等価加硫時間(ECT) は温度係数(TC)を用い て, 温度の時間変化を積分することにより計算し た.

$$
E C T=\int_{0}^{t} T C^{\theta-\theta \operatorname{ref} / 10} \cdot d t
$$

ここで $\theta_{\text {ref }}$ は基準温度である. 温度係数は, 温 度上昇 $10^{\circ} \mathrm{C}$ 当たり, $90 \%$ 加硫に達する必要時間 の比として定義される．すなわち， $T C<1$ であ る. また加硫度は, 以下によって, 等価加硫時間 と関係づけられている：

$$
\begin{gathered}
c=100\left(1-\exp \left(-\lambda\left(E C T-t_{i}\right)\right)\right) \\
\lambda \text { 速度定数 } \\
t_{i} \text { 誘導時間 }
\end{gathered}
$$

最終的に, 以下によって加硫は対流移動する.

$$
\frac{D c}{D t}=\frac{\partial c}{\partial t}+u \frac{\partial c}{\partial n}
$$

ここで $n$ は流れの方向である.

$$
\text { 3. コンピューターソフトウェア }
$$

前述したモデルをソフトウェア化するために は, 複雑な数学的モデルに関する熟練が要求され る.しかし，このようなソフトウェアの価值は， 非常に単純な項目で評価することができる.

(i) このようなソフトウェアは簡単に操作できる こと

(ii） その有効性に対する費用が安い

(iii) 複雑な数学的モデルを成型業者と金型設計者 に理解しやすいようにしたこと

射出成型サイクルのシミュレーションでは, 多 くのパラメーターが計算される。しかし，コンピ ューターは完全には経験に取って代わるものでは ない，充分に満足のできる金型を製作するため に，必要とされる情報を得るためには金型設計者 によりある程度の解釈が必要とされる．この種の 典型的な情報は：
(i) 金型は完全に充てんされるか.
(ii) 加工条件は最適化されているか.
(iii) ウェルドラインはどこか.
(iv) ベントはどこか.

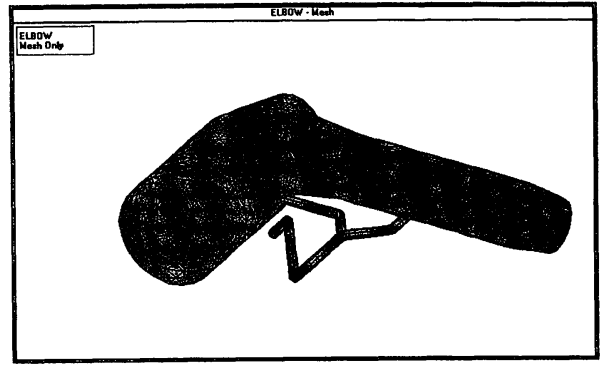

図 2 有限要素法とフィードシステム

（v）材料はコスーチされたか.

与えられた金型に完全に充てんすることは，金 型の形状，材料の温度，充てん速度等の加工条件 によって決定される. 加工条件を最適化すること により，最短のサイクル時間と最大のエネルギー 節約となる. ウェルドライン位置は, 充てんがう まく行われなかったときには，強度の足りない部 分となる可能性がある。またエアーベントが適切 な位置になければ，これもまた欠陥製品の基とな る.

このような問題点は，どうして解析が必要かと いう理由となる．解析は，金型設計者が，この種 の問題点を解決するのを手助けする，マルチゲー トキャビティーの場合, フィードシステムを構成 するランナーやゲートの形や大きさと加工条件を 変えることにより, ウェルドラインやベントの位 置に影響を及ぼす．また条件の変更は，金型全体 の充てんのバランスを取ることも可能である。こ のような作業が，実際に金型を製作する前に、 コ ンピューターソフトウェアを使用することにより わずかな時間と費用で可能となる。

\section{4. シミュレーションの例}

上述された数学的モデルが, パッケージソフト ウェアになり発売された. 以下の例は, 金型設計 者により実際に行われている典型的な解析を示し ている.

図 2 の L 字管のような三次元の部品は, 表面 モデラーを使用することにより簡単に記述でき る、また，自動メッシュ形成システムによりよ り簡単にモデル化することができる. キャビティ をメッシュ化するのに, 三角形の二次元シェル要 素を使う。ランナーとゲートは, シリンダー形の 一次元要素によりモデル化する. 厚みと個々の表 


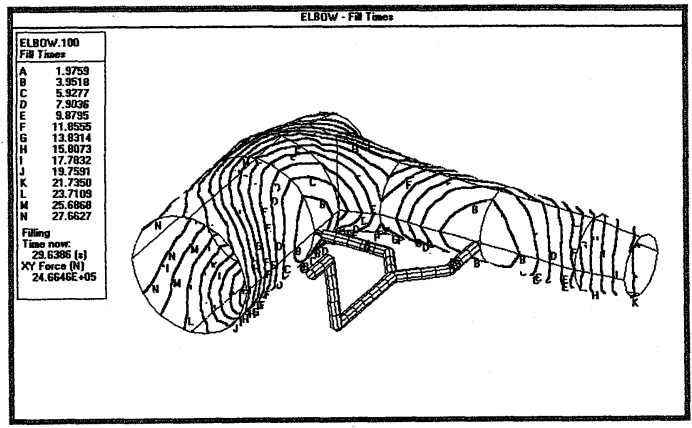

図 3 充てんパターン

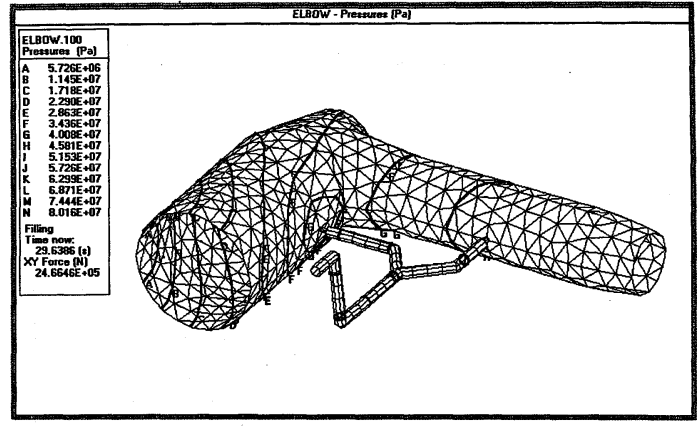

図 4 充てん時点の圧力分布

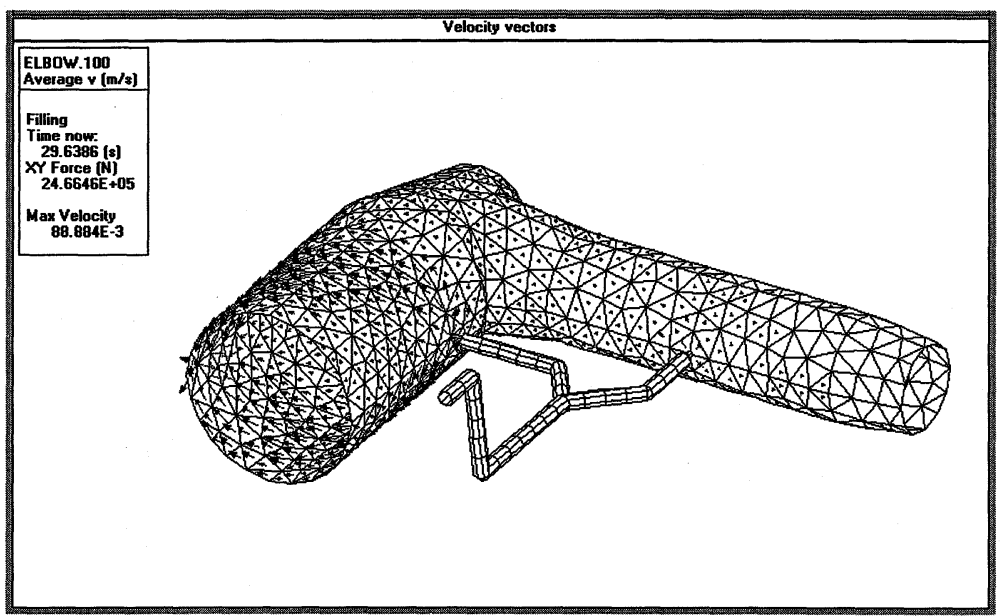

図 5 充てん終了時点の速度分布

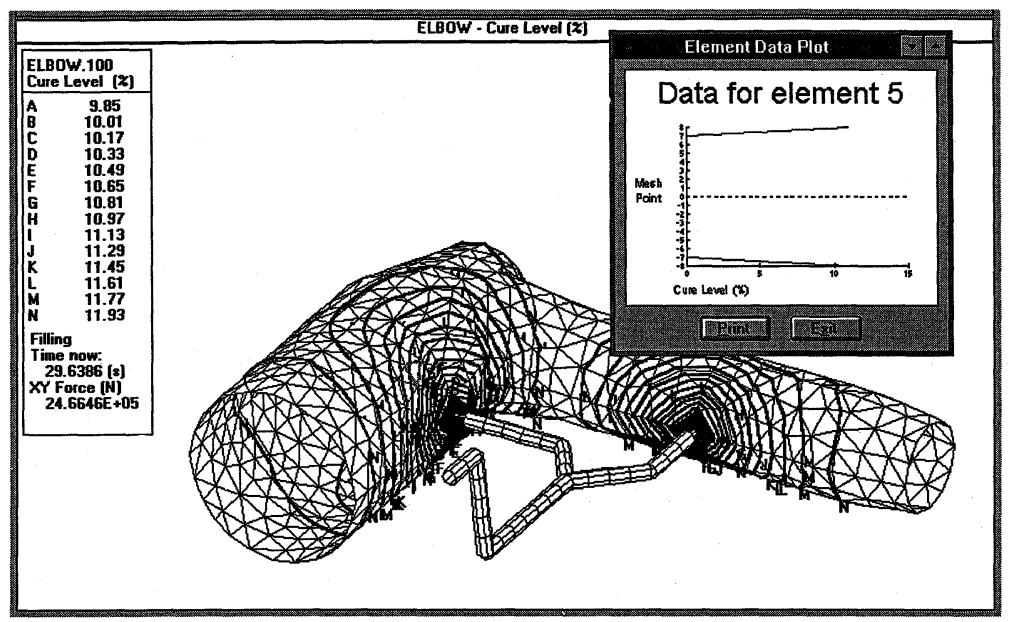

図 6 充てん終了時点のキャビティ内の最大加硫分布 


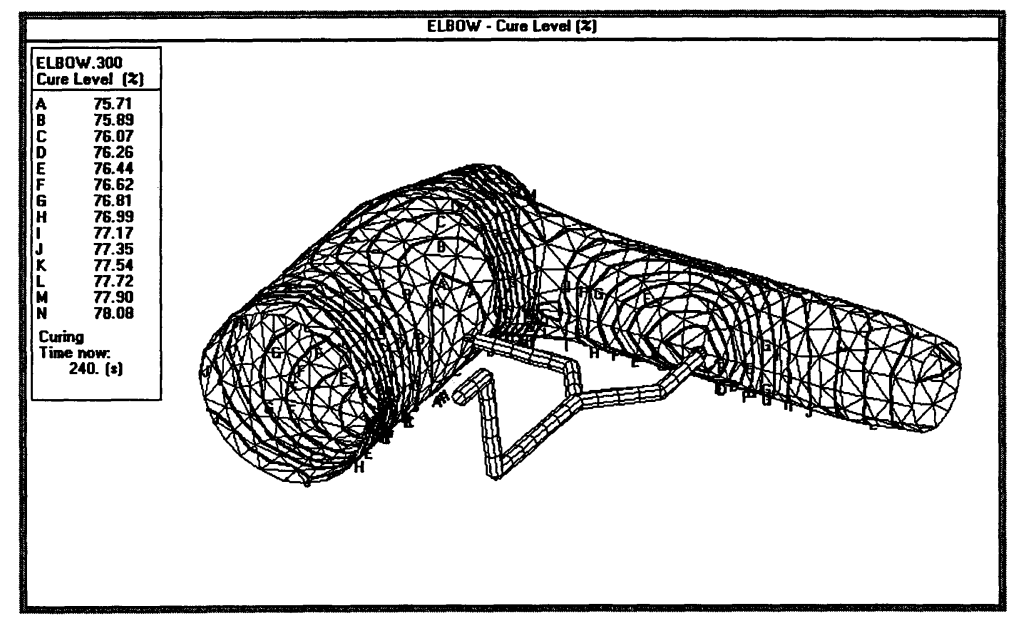

図 7 サイクル終了時点の最小加硫分布

面の金型壁面の温度は独立に決められている．以 下の解析では，材料は EPDM コンパンドを使用 する.

金型の大きさは，全長 $340 \mathrm{~mm}$ で，直径 100 $\mathrm{mm}$ と $60 \mathrm{~mm}$ の 2 本のパイプをつなぎ合わせた あのである．ここでは，充てん時間を30秒，金型 温度は一様に $180^{\circ} \mathrm{C}$, 材料のストック温度は $80^{\circ} \mathrm{C}$ とする。一サイクル時間は，240秒とする．図 3 は, フローフロントの等時位置によって示された 充てんパターンを示している.この図より，最後 の充てん部分としてウェルドラインが視覚化され る.このことは, ベント位置を正しい位置に作る のに極めて重要である.

図 4 は，充てんする瞬間の圧力分布を示してい る.フィードポイント地点に打ける最大圧力は, $85.3 \mathrm{MPa}$ となっている. 普通の圧力を出せる射 出成形機で充分に金型を充てんできることを示し ている．金型を締める力は，2,466.46 kN で， 251.4トンに相当する.

四 5 には充てん時点での速度分布を示してい る. 速度の速い場所は，充てんすべき金型の最終 場所を示している．繊維等を多量に配合された材 料では, 速度分布は, 製品内部での繊維方向に関 する定性的情報を与えることとなる．繊維方向と 異方性材料特性の完全な予測のためには，速度へ クトルの前の材料の流れの履歴を考虑することが 必要である。いくつかの基本的なモデルは，既に
作られているが10)，この分野におけりる研究は今後 も継続されなければならない。

図 4,5のデータは充てんの瞬間の分布を示し ている.他の充てん時間でのプロットから，充て んに関する完全な時間経過がわかるようになる。

例えば，完全な充てんパターンを使用したときに は，はっきりしなかったと思われるベントとウェ ルドラインを確認できる.

図 6 では, 充てんの最後の時点における最大加 硫度がキャビティ内でおよそ $12 \%$ であることを示 している. 加硫度のキャビティの厚さ方向の分布 は，金型壁面に隣接した材料が最大の加硫度であ ることがわかる。このために表面に欠陌が生じ不 良品となる，このソフトウェアは，様々な加工条 件で試験することにより，このような影響を最小 限とすることができる，最大の加硫度は，ゲート の周辺に見られるので, このような問題を解決す るためには, ゲートデザインの変更が最も効果が 高いと思われる。

サイクル時間は，充てん時間と加硫時間の合計 として決められる. 加硫時間は, 加硫過程の様々 な時点における厚さ方向の加硫プロフィールを解 析することにより決めることができる. 図 7 に示 されている各点は, サイクルの最終段階で，製品 の厚さ方向の各ノードでの最低加硫レベルを表わ している.この数値を観察することにより製品を いつ金型から取り出したら良いか判断できる. 形 
の安定性や気孔の状態といったその他の条件によ っては金型から取り出す前に完全に加硫の終了が 必要とされることもありらる. 図 7 の例では, 240 秒でキャビティ全体に対して，75\%以上の加 硫度を示している. そして完全に加硫の終了が必 要とされることもありらる. 金型から取り出した 後加硫が充分になされるよらに熱を保持したまま 製品を取り出すことができる.

\section{5. 結論}

この論文は, 射出成形の基本理論を説明し, こ の理論を使用したソフトウェアを使う利点を示し た．材料特性，加工条件，金型の形状といった独 立した変数を容易にシミュレーションできる。 入 カデータを適切に変えた後で, 一連の流動解析を することにより, 以下のような恩恵に預かること ができる.

(i) 適切な金型の充てん

(ii) 加工条件の最適化

(iii) サイクル時間の最小化

(iv) ウェルドライン位置の予測

(v) ゲートの位置と設計

(vi) マルチキャビティ用ランナーのバランス

(vii) 材料評価

(viii) スコーチの回避

このよらな利点については, 射出成形品の設計, 開発，生産に携わる者すべてが評価できるもので ある。

この結果, 以下の達成が可能となり製造業者にと っては自社の競争力の向上を意味する.

1）市場に短時間に製品を供給できる.

2）最適化された充てんおよび加硫条件の基で, 適切なウェルドとベント位置を持ち, 製品の品 質向上
3）最小のサイクル時間により，生産性が向上す る.

\section{REFERENGES}

1) Hieber, C. A. and Shen, S. F.: "A Finite Element/ Finite Difference Simulation of the Injection Filling Process", J. Non-Newtonian Fluid Mech., 1980, 7, pp 1-32

2) Sobhanie, M. and Isayev, A. I.: "Simulation of Injection Moulding of Rubber Compounds" in Modelling of Polymer Processing, A. I. Isayev. Ed., Hanser Publiseers (1991)

3) Wang, H. P. and Lee, H. S.: "Numerical Techniques for Free and Moving Boundary Problems' in Computer Modelling for Polymer Processing, C. L. Tucker. Ed., Hanser Publishers (1989)

4) Winslow, A. M.: "Numerical Solution of the Quasilinear Poisson Equation in a Nonuniform Triangular Mesh", J. Computational Physics, 1967, 2, pp 149-172

5) Patankar, S. V.: Numerical Heat Transfer and Fluid Flow, Hemisphere Publishing Corp., New York (1991)

6) Hirt, C. W. and Nichols, B. D.: "Volume of Fluid (VOF) Method for the Dynamics of Free Boundaries", J. Computational Physics, 1981, 39, pp 201-225

7) Tadmor, Z., Broyer, E. and Gutfinger, C.: "Flow Analysis Network (FAN)-A Method for Solving Flow Problems in Polymer Processing", Polymer Eng. Sci., 1974, 14, pp 660-665

8) Kamal, M. R.: "Thermoset Characterisation for Moldability Analysis", Polymer Eng. Sci., 1974, 14, pp 231-239

9) Hands, D. and Horsfall, F.: "A new Method for Simulating Industrial Cure Processes", Kautshuck Gummi Kunststoffe, 1980, 33, pp 44-46

10) Advani, S. G. and Tucker, C. L.: "Numerical Simulation of Short Fibre Orientation in Compression Moulding", Polym. Composites, 1990, 11, pp 164-173 